and Marc Bechard provided constructive comment of an earlier version of this paper. An anonymous reviewer must be credited with many improvements.

1. EWINS, P.J. and C.S. HOUSTON. 1992. Recovery patterns of Ospreys, Pandion haliaetus, banded in Canada up to 1989. Canadian FieldNaturalist 106:361-365.
2. HOUSTON, C.S. and F.S. SCOTT. 1992. The effect of man-made platforms on Osprey reproduction at Loon Lake, Saskatchewan. Journal of Raptor Research 26:152-158.

3. SCOTT, F. and C.S. HOUSTON. 1985. Success of Osprey nest platforms near Loon Lake, Saskatchewan. Blue Jay 43:238-242.

\title{
SUCCESSFUL FOSTERING OF TWO GREAT HORNED OWL CHICKS
}

JARED B. CLARKE, 323 Habkirk Drive, Regina, SK S4S 6A9. E-mail: <clarkejared16@yahoo.ca>

At noon on May 19, 2007, I received a phone call from Doug Kemp concerning an active Great Horned Owl nest in his yard in the town of Pasqua, SK. That morning, a SaskPower employee notified Doug that a Great Horned Owl had landed on the transmitter box approximately $50 \mathrm{~m}$ from his home and had been killed. Three weeks earlier, Doug had found an adult owl in his yard that had apparently died from natural causes. Presuming that both parents were now dead and the owlets were orphaned, Doug collected the two chicks, approximately 5 weeks old and in good condition, and brought them to me in Moose Jaw.

After discussing options with Stuart Houston, who in past years had successfully fostered single orphaned owls into active nests, I decided to do the same. I wanted to place each of the orphaned chicks into a nest containing only one chick, but of the 32 active nests in the Regina and Moose Jaw area that I had found in spring, I knew of only one that contained a single chick. While banding that owlet (\#788-56510, hereafter \#10) on May 6 , I found that its nest was overflowing with food: the remains of two Gray Partridge, one Blue-winged Teal, a Richardson's Ground-squirrel, a Western Meadowlark, a sandpiper and a Shorteared Owl. I chose to place both owlets into this nest, as adding two chicks would not exceed the normal clutch size (2 to 3 ) for this species and the abundance of food suggested the adults should be capable of providing for all three chicks.

On the evening of May 20, 2007, Elizabeth Travis and I placed the two orphans (band \#788-56563 \& 78856564, hereafter \#63 \& 64) into this nest. Owl \#10 was easily distinguished from \#63 \& 64, as it was a week and a half older and its feathers were quite orange compared to the paler-gray, younger birds. (See inside front cover.) This difference was apparent from our viewing point on the highway, $150 \mathrm{~m}$ away.

All three chicks remained in the nest for the next 6 days. On the morning of May 27, the nest was empty but two chicks were located nearby in different trees: bird \#10 and one of the orphans. The orphan had the back end of a duck cached beside it, which indicated that the adults had accepted the orphaned 
chicks as their own and were supplying them with food. On June 3, my last visit, all three chicks were seen perched in a single tree $15 \mathrm{~m}$ from the nest and were capable of flying well.

My two concerns when adding these chicks to this nest were that the adults would kill the new birds immediately or that the adults would not feed the new chicks. In this case, the adoption was apparently successful. Great Horned Owls appear to readily adopt chicks that are similar in size to their own, provided that the total number does not exceed a normal clutch. This technique is an effective way of dealing with orphaned owls. Ideally, the orphan(s) should be younger than the original chick(s), so as not to affect the chance of survival of the original $\operatorname{chick}(\mathrm{s})$.

\section{Acknowledgments}

Thanks to Stuart Houston for his advice and helpful comments on this manuscript. Also thanks to Doug Kemp for his watchful eye and passion for these owls, and to Elizabeth Travis for her help in the field.

\section{SWAINSON'S HAWK RESPONSE TO FIRE AT LAST MOUNTAIN LAKE NATIONAL WILDLIFE AREA, SK}

PHILIP S. TAYLOR, Canadian Wildlife Service, 115 Perimeter Road, Saskatoon SK, S7N OX4

The Canadian Wildlife Service has conducted over 50 prescribed burns at Last Mountain Lake National Wildlife Area (LMLNWA), beginning in 1980 , to manage the native grasslands and improve habitat for migratory birds and other wildlife. Our observations of diurnal raptors responding to fire are very similar to the experiences at Lostwood National Wildlife Refuge, ND. ${ }^{1}$

Our burns are most frequently done in late March to early June, less frequently in mid-August to early November, and range in size from under one hectare to over 280 ha. Raptors normally arrive at LMLNWA at different times: Ferruginous Hawk and Northern Harrier in late March or early April; Red-tailed Hawk in early to midApril; and Swainson's Hawk in mid- to late April. Abundance of these raptors during the breeding season at LMLNWA varies between years but the averages in recent years are Ferruginous Hawk (0-1 pair), Redtailed Hawk (<5 pair) and Swainson's Hawk (15-30+ pair). Northern Harrier are a common nesting species but no quantitative data are available. ${ }^{2}$ LMLNWA is near the northern limit of the breeding range of Swainson's and Ferruginous hawks, approximately $340 \mathrm{~km}$ north of Lostwood National Wildlife Refuge. Therefore, hawks present in our area are most likely to be summer breeding residents, rather than migrants.

Swainson's Hawks, when present at LMLNWA, arrive at large prescribed burns soon after the fire is started and often within the first 30 minutes. Hawk numbers observed are lower than at Lostwood National Wildlife Refuge, usually between 1 and 6 individuals at any one time. During a burn in the second week of April 1992, two Swainson's Hawks arrived on site, 